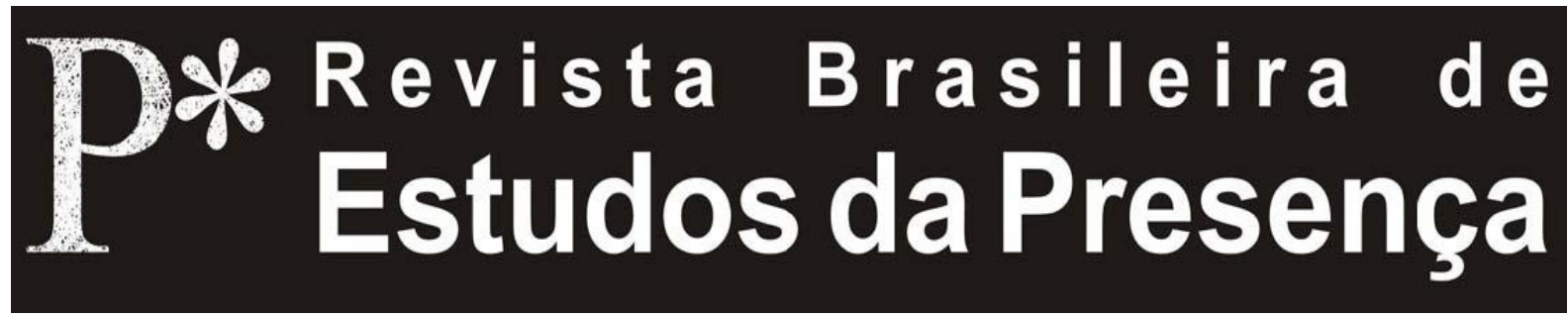

DOI - http://dx.doi.org/10.1590/2237-266039703

ISSN 2237-2660

\title{
Teatro Pós-dramático, doze anos depois
}

\author{
Hans-Thies Lehmann \\ Johann Wolfgang Goethe-Universität Frankfurt am Main - Frankfurt, Alemanha
}

RESUMO - Teatro Pós-dramático, doze anos depois - Este texto faz um balanço dos doze anos de emergência da prática e do termo Pós-dramático e alguns de seus desdobramentos e questóes para as artes cênicas. Discutem-se as mudanças pelas quais a cena contemporânea foi protagonista desde 1999 e, em consequência, as mudanças que devemos considerar ao ler e analisar o pós-dramático; entre elas, a ênfase no trabalho colaborativo; as novas relaçóes entre teatro e sociedade; os usos do coro; a atenção à dança; o retorno da palavra. Por fim, o texto coloca a questão de saber se o termo pós-dramático precisaria ou não ser revisto.

Palavras-chave: Teatro Pós-dramático. Hans-Thies Lehmann. Espetáculo. Cena Contemporânea. Artes Cênicas.

ABSTRACT - Postdramatic Theatre, 12 years later - This text takes stock of the twelve years of emergence of the practice and term Postdramatic and some of its developments and issues in the performing arts. It discusses the changes through which the contemporary scene has gone since 1999 and consequently the changes we should consider when reading and analysing the concept of postdramatic; among them, the focus on collaborative work; new relations between theatre and society; the focus on dance; and the return of words. Finally, the text raises the question of whether or not the term postdramatic should be reconsidered.

Keywords: Postdramatic Theatre. Hans-Thies Lehmann. Spectacle. Contemporary Scene. Performing Arts.

RÉSUMÉ - Théâtre Postdramatique, douze ans plus tard - Ce texte dresse un bilan de la pratique et du terme postdramatique, depuis son émergence il y a douze ans, et de certains de ses développements appliqués aux arts du spectacle. Il propose une réflexion sur les bouleversements qu'a connu la scène contemporaine depuis 1999 et sur l'évolution du mode de lecture et d'analyse du postdramatique qui en découle. L'accent est mis sur le travail collectif; les nouvelles relations entre le théâtre et la société; les usages du cœur; l'attention portée à la danse; le retour du mot. Pour finir, le texte s'interroge sur éventuelle remise en question du terme postdramatique.

Mots-clés: Théâtre Postdramatique. Hans-Thies Lehmann. Spectacle. Scène Contemporaine. Arts du Spectacle. 
Escrevi Teatro Pós-dramático ${ }^{1}$ com a intenção de ajudar aqueles que tentavam encontrar e utilizar conceitos e palavras, e dar bastante atençáo a muitos trabalhos artísticos experimentais no teatro e na performance. Testemunhei essas produçóes por décadas e queria que elas fossem compreendidas e avaliadas de maneira melhor do que as usuais. $\mathrm{O}$ livro, na realidade, tem sido, às vezes, interpretado como uma justificativa e defesa desqualificada de todos os tipos de performances aparentemente destrutivas, desconstrutivas, fragmentárias e não-literárias - o que não era a minha intenção. A poética, se assim preferir, do teatro pós-dramático, que é constituído por sua descrição, é uma coisa, a qualidade artística (mesmo que agora náo seja mais fácil fazer uso desse termo sem grande precaução) é outra.

O estudo foi escrito para profissionais, por isso, em alguns trechos, as elaboraçóes teóricas longas e detalhadas foram omitidas. Consequentemente, uma série de problemas teóricos foi deixada em aberto para futuras discussões mais aprofundadas. Ele também abriu o caminho para uma série de francos mal-entendidos - que o pósdramático é não-textual, que o pós-dramático termina com todo o drama e assim por diante -, apesar do fato de que as visóes opostas sejam claramente afirmadas no livro. A palavra pós-dramático descreve estéticas e estilos da prática teatral e tematiza a escrita, o drama escrito ou o texto teatral apenas de forma marginal. Há formas de teatro pós-dramático com textos dramáticos - na realidade, com todos os tipos de texto. Além disso, há uma descrição no livro de uma variedade de formas teatrais, desde a apresentação des-dramatizada de textos dramáticos até formas que não dependem de modo algum de um texto dramático pré-definido. Há uma série de importantes novos estilos de escrita que surgiram desde 1999 - ou já estavam presentes naquela época -, mas eu não vejo o retorno à figuração dramática como um movimento de peso.

Entretanto, doze anos é um longo período atualmente, com desenvolvimentos nas artes e no teatro acontecendo em ritmo táo acelerado. Muito do que era marginal e discutido calorosamente na década de 1980 já havia se tornado comum nos anos 1990, e agora já é parte do mainstream. Alguns dos protagonistas emblemáticos do teatro pós-dramático, como Jan Fabre e Jan Lauwers, cujo trabalho é fortemente influenciado pela dança e pela performance, continuam a criar trabalhos fortes e polêmicos e passaram a ser aceitos como gestos autênticos e mesmo decisivos da arte e do teatro contemporâneos. 
Você - ou eu - não teria adivinhado, em 1999, que Jan Lauwers estaria se apresentando no Salzburger Festspiele, ou que Jan Fabre seria escolhido como curador do Festival de Avignon. A estética de Robert Wilson já é comercializada há muito tempo e seus trabalhos são agora apreciados por um público muito amplo. $\mathrm{Na}$ Itália, um artista como Barberio Corsetti, que vem de trabalhos inovadores em vídeo, no teatro, tornou-se diretor da Biennale di Teatro em Veneza.

Por outro lado, náo deve haver qualquer dúvida de que as técnicas da dramaturgia visual têm a tendência agora de se tornar mero espetáculo nas grandes casas de espetáculos, sendo apresentadas como entretenimento em muitas produções de caráter mais ou menos tradicional. Em outras palavras, o pós-dramático não é mais um termo que denota práticas desviantes, de oposição ou radicais. Os elementos da prática pós-dramática tornaram-se geralmente aceitos e definem muito da prática do teatro contemporâneo como tal - não sem muitas vezes perder vantagens nesse processo.

$\mathrm{Na}$ primeira parte do meu artigo, falarei sobre uma série de interessantes desenvolvimentos e aspectos das "linguagens do palco" (Pavis, 1982), principalmente no teatro alemão. Alguns deles dão continuidade a desenvolvimentos que começaram a ser percebidos já nos anos 1980 e 1990, enquanto outros introduzem novas ênfases.

$\mathrm{Na}$ segunda parte, farei uma reflexáo sobre algumas das questóes e aspectos que parecem importantes para uma teorização posterior do paradigma ou estilos pós-dramáticos.

\section{Grupos}

Em 1995, Heiner Müller e, em 2001, Einar Schleef faleceram, e também recentemente faleceram Jürgen Gosch, Peter Zadek, Klaus-Michael Grüber, Pina Bausch, e Christoph Schlingensief. Acredito que essas mortes sejam um sinal e um símbolo de tempos de profundas mudanças. Eles todos foram grandes criadores que representavam o melhor do teatro de diretor alemão. Eles abriram novos caminhos para o teatro: trabalhando nos limites da performance (como Gosch), criando um cross-over entre o teatro e a dança (Pina Bausch), uma jocosidade que conecta a estética popular com a erudita (Zadek) e, como sempre, uma visáo radicalmente individual do teatro (como Grüber). Mesmo a morte prematura de Christoph Schlingensief pode ser vista através deste prisma: uma personalidade 
altamente instigante, radical e radicalmente idiossincrática, mesmo que ele tenha sido um inspirador, um animador, mais do que um diretor no sentido clássico. O novo desenvolvimento é marcado esse é o primeiro aspecto - por uma mudança de ênfase do gênio individual em primeiro plano para o trabalho colaborativo ou em grupo dentro e fora das instituiçóes. Apesar do fim de uma série de locais importantes para o trabalho experimental, observamos um panorama amplo de trabalhos de performance e teatro jovens e semi (ou não) institucionalizados - em sua maior parte, de grupos que experimentam com todos os tipos de posicionamento do espectador, redefinindo o teatro de formas diferentes para além do modelo dramático. Não se pode chamá-lo exatamente de underground. Ele é um panorama no qual nomes como She She Pop, Gob Squad, Andcompanry \& Co., Hoffmann e Lindholm e outros, assim como o aclamado Rimini Protokoll, indicam apenas a ponta do iceberg. Autores que dirigem seus próprios textos, como Rene Pollesch ou Falk Richter, e a colaboração próxima entre autores, dramaturgos e cenógrafos são agora muito frequentes. Definitivamente, há um espírito renovado de estilo de trabalho colaborativo, mesmo de um modo que difira totalmente do trabalho coletivo. Veja Rene Pollesch, que nunca inicia um novo espetáculo de teatro com um texto completo, mas oferece parte dele e pergunta aos performers se eles o acham interessante. $\mathrm{O}$ artista do teatro não quer ser um serviçal dos espectadores, ele náo quer tratá-los como espectadores, mas sim, articular algo no palco que esteja nas mentes das próprias pessoas do teatro.

Ao trabalhar de modo coletivo, mesmo que certamente não sem uma voz dominante e inspiração de um único artista, o pop-theatre de Réné Pollesh ganhou grande ressonância e abriu o caminho para outras formas semelhantes de teatro. Barbara Weber, atualmente diretora do Neumarkt Theatre em Zurique, é um caso em questão aqui, com as suas noites unplugged e também com as suas interpretaçôes inovadoras de textos clássicos - The Lears, por exemplo, no qual o Rei Lear foi associado à questáo da família. O grupo feminista She She Pop também fez referências ao Rei Lear, de Shakespeare, ao pedir que os pais das atrizes aparecessem com elas no palco para então iniciar alguns debates animados sobre as respectivas posiçóes dos pais e de suas filhas. Essa performance tornou-se um grande sucesso, tendo sido aclamada pela crítica e apontando para o fato de que a noção básica de teatro se distancia do paradigma dramático. 
Nesse ambiente, encontramos uma produçáo original que, de alguma forma, pode ser chamada de site specific. Os espectadores são convidados a visitar habitaçóes privadas, entrar em alguns ambientes especiais por algumas horas e experimentar uma situação incomum com performances, leituras ou apresentaçóes. O objetivo é criar uma situação de exploração ou mesmo de pesquisa e de encontros pouco usuais. Há profundo interesse em se trabalhar em ou com locais urbanos e outros locais públicos ou semipúblicos. O espaço da cidade, as realidades arquitetônicas e sociais do ambiente urbano, tem sido explorado (como é o caso do Rimini Protokoll, mas também de grupos menos conhecidos como o Arty Chock de Frankfurt, que apostam em locais públicos para evidenciar, de modos teatralmente criativos, algum significado político ou sociológico do local). Projetos desse tipo frequentemente usam vídeos ou transformam um dado local em um espaço recém-definido e investido de um caráter artístico e político.

O trabalho de Pollesch tornou-se cada vez mais político de um modo sofisticado, não mais tematizando apenas os problemas da dimensão virtual do trabalho, mas também conceitos básicos do estilo de vida capitalista. Entre os títulos de suas produçóes podemos agora encontrar Darwin-win e Calvinism Klein. Ele é geralmente reconhecido como um dos mais criativos produtores de trabalhos cômicos politicamente relevantes. Em uma atmosfera festiva ou em um ambiente de clube, os personagens que falam (que são, na verdade, instâncias coletivas do discurso e não dramatis personae individuais) desenvolvem questóes teóricas no palco, frequentemente em forma de discurso teórico modificado da terceira para a primeira pessoa. Isso pode produzir diálogos ambíguos e divertidos que, na verdade, não constituem diálogos reais, mas um coro dividido em vozes, apresentando questóes sociológicas e políticas e denunciando, de forma satírica, as ideologias da representação, subjetividade, identidade, ou desejo pré-codificado pelo poder das normas culturais e sociais. De outra forma, Pollesch, em parceria com Fabian Hinrichs, criou performances poderosas e mais ou menos monológicas que colocam o público do teatro em uma posiçáo na qual ele é constantemente abordado e tematizado.

\section{Diálogo entre o Teatro e a Sociedade}

O desenvolvimento de Pollesch é significativo para um segundo e forte impulso no teatro da primeira década deste século: a saber, 
o impulso de reabrir o diálogo entre o teatro e a sociedade através da tomada direta de questôes políticas e sociais. É justo dizer que, no entusiasmo de se encontrar (e experimentar com) os novos meios artísticos pós-dramáticos - dramaturgia visual, mídia, fragmentação, atuação performática, abertura de espaços reais e virtuais -, esse diálogo havia, até certo ponto, se perdido no trabalho pós-dramático descrito há dez anos. Em 2000, Bonnie Maranca e Gautam Dasgupta (2000), em uma entrevista para a Theater der Zeit, expressaram grande decepçáo ao considerar que o teatro alemáo era diferente do que eles haviam previsto nos anos 1970: menos audacioso, política, filosófica e artisticamente, com muito espetáculo e pouco "diálogo com a sociedade". As razóes para uma certa reentrada da dimensão política e social desde então são bastante óbvias: o onze de setembro, novas guerras, a ascensão de líderes políticos de direita na Europa, a reestruturação completa do campo político e ideológico depois do Wende e, por último, mas náo menos importante, novos tipos de problemas sociais associados a uma crise financeira sem fim. $\mathrm{O}$ teatro definitivamente sentiu e sente a necessidade de lidar mais diretamente com as questôes políticas, mesmo que não existam soluçóes ou perspectivas a oferecer. Temos algo em comum com boa parte do teatro politicamente motivado, mas raramente no sentido de oferecer um ponto de vista ideológico específico. Há espetáculos - na verdade, uma onda de espetáculos - sobre homens de negócios, iniciada com Top Dogs, de Urs Widmer, e com a complexa The System, de Falk Richter, como um ponto alto, mas seguida de outros trabalhos de peso, como Trust, Protect Me ou In a state of exception. Entretanto, não encontramos um grande retorno ao drama socialmente engajado, mas a todos os tipos de misturas, reelaboraçóes de trabalhos documentais, estética da performance, açóes teatrais e atividades - todas com um foco notavelmente estável na dança, assim como no teatro e na exploraçáo da vida cotidiana (a popularidade de autores como Michel de Certeau (1980) e Marc Augé (1992) é significativa nesse sentido). O teatro e a performance são mais sobre a pesquisa da vida cotidiana que acreditamos conhecer muito bem. Suas técnicas são mais apresentação do que representação, mais uma exposição astuta das realidades e da criaçáo de teatros de situação do que uma representação das ficçóes dramáticas sobre eles - embora essa prática certamente não tenha desaparecido por completo. 
A estética da fisicalidade, assim como da alta tecnologia, computadores, internet e vídeo, podem se tornar ferramentas e um ambiente para um despertar do interesse social e político. $\mathrm{O}$ trabalho do Rimini Protokoll sem atores profissionais, no qual o encontro com pessoas reais é mais importante do que a dramaturgia de uma ficção, ganhou grande visibilidade, mas há um grande número de trabalhos menores no espírito do documentário, que, inspirados pelo Rimini Protokoll, frequentemente usam não-atores para uma série de explorações da vida cotidiana. Assim, Hans Werner Krösinger, por exemplo, e outros levam ao palco documentos e materiais políticos de formas bastante sofisticadas. Ou entáo encontramos o teatro sobre a história pessoal de indivíduos em um contexto político - inspirado pelas técnicas da história oral da área acadêmica.

A principal questão artística em muitos desses trabalhos não é simplesmente a escolha do trabalho apresentado, mas a questão de como se desenvolver, o que Marianne van Kerkhoven (2009) chamaria de dramaturgias do espectador. A dramaturgia pós-dramática implica uma consciência maior e uma contínua reflexão sobre a posiçáo do espectador como tal. Por mais que seja compreensível o desejo de se tematizar as questóes sociais e políticas, não devemos esquecer que a dimensão realmente social da arte é a forma, como o jovem Georg Lukács observou. Na medida em que as formas convencionalizadas de recepção não forem interrompidas, o modo tradicional de recepção no teatro (e no cinema) tenderá a reduzir à insignificância até mesmo a documentação e crítica política mais audaciosa. Por isso, ainda é essencial reconhecer que a dimensão verdadeiramente política do teatro tem seu lugar náo tanto na tematizaçáo de assuntos politicamente importantes (que, ao se afirmar isso, obviamente náo estáo excluídos) como na situação, relação, movimento social que o teatro como tal é capaz de constituir. O teatro deve ser considerado como uma situação, e a sua estética deve derivar desse conceito básico. Aparentemente, as estratégias pós-dramáticas continuam sendo vistas por muitos profissionais do teatro como as mais adequadas para se discutir questóes sociais (desemprego, violência, isolamento social, terrorismo, questóes raciais ou de gênero) do que o modelo tradicional de drama socialmente engajado. $\mathrm{Na}$ realidade, houve o surgimento de um movimento evidente nos primeiros cinco anos do novo século: o neorrealismo, proclamado por alguns diretores com referência à tradiçáo inglesa de trabalhos realistas e socialmente 
críticos. No entanto, apesar da fama internacional de Thomas Ostermeier, essa onda se abrandou muito. Eu não tenho a impressáo de que muitas pessoas esperem novas e interessantes revelaçóes do teatro nesse sentido. $\mathrm{Na}$ verdade, o impacto maior e mais profundo do movimento in-yer-face foi a recepção de Sarah Kane, cuja escrita voltou-se gradualmente para a direção oposta aos resquícios do drama em suas primeiras peças, como Blasted e 4.48 Psychosis, sendo um exemplo quase ideal de textura pós-dramática.

\section{Coro}

Em 2001, o teatro alemão perdeu Einar Schleef e, com ele, o diretor que havia redescoberto o poder do coro como ferramenta e elemento básico do teatro. Inspirado por seu trabalho, há agora muito teatro que faz amplo uso da estrutura coral de diferentes maneiras. Esse desenvolvimento merece ser mencionado como uma tendência em si mesma. Obviamente, o interesse pelo coro enfraquece ainda mais as estruturas básicas da representação dramática. Desde a antiguidade, o coro tem sido uma realidade teatral que abre e rompe com o cosmos ficcional do mito ou narraçáo dramática e póe em jogo a presença do público aqui e agora no teatro - no theatron. (Essa é uma das razóes pelas quais o coro náo foi capaz de encontrar um lugar na Poética, de Aristóteles, cujo foco principal era o encerramento da obra de arte, sua totalidade autossuficiente e sua completude). Apesar de Einar Schleef parecer ser apenas uma figura solitária nesse retorno do coro, desde os tempos em que suas produçóes provocaram enormes debates na Alemanha, o uso e a discussão sobre o coro náo terminou, mas ganhou mais terreno. Aqui poderíamos mencionar os trabalhos de Volker Lösch, que trabalha com o contato com o público e com os coros - por exemplo, os desempregados e moradores da área, para articular questóes sociais e políticas. Sua obra causa reaçóes polêmicas - e, de fato, provoca, muitas vezes, a suspeita de que ele se beneficia em especial da miséria social para efeitos espetaculares sem refletir muito e sem questionar o aparato teatral que ele utiliza. Mas não é apenas no domínio desse teatro diretamente politico que um retorno do coro pode ser observado. É revelador o fato de que um diretor como Nicolas Stemann também apresente The Robbers, de Schiller, em estilo coral (performers compartilhando e trocando de papéis, criando com a voz e com gestos um concerto de palavras, como Stemann o chama, na forma de uma banda de jazz ou rock). Claudia 
Bosse, em seguida, realizou uma montagem de Os Persas na qual os atores e o público dividiam o mesmo espaço, movendo-se como um coro e de novo como protagonistas ao lado dos espectadores que náo se sentavam, mas permaneciam em pé ou circulavam pelo espaço.

\section{Dança}

Outra tendência - depois do modo colaborativo de produção, o diálogo com a sociedade, e o retorno do coro - é o enorme e generalizado interesse pela dança, a divulgação de trabalhos teóricos e práticos com, de, e sobre a dança.

William Forsythe explora a mistura entre dança, instalação, performance, evento festivo, interatividade e referência política em trabalhos como Human Writes. Meg Stuart combina, por um lado, a dança e a exploraçáo minimalista do gesto em consonância com ambientaçóes imensas e espetáculo teatral; por outro lado, com trabalhos poéticos em pequena escala. Constanza Macras e outros realizam uma politização da dança-teatro, transitando livremente entre a dança, a performance, o teatro físico, a atuaçáo teatral e a instalaçấo. A dança tornou-se uma prática que é recebida de forma muito mais ampla e tem exercido influência sobre muitos aspectos da prática teatral. A cultura política do estado alemáo tem sido ávida por muitos anos em apoiar a dança com um projeto financeiro grandioso chamado Tanzplan. A dança, também, é um fator essencial na reconsideração e revisão das noções teóricas do que pode ser uma crítica adequada e um discurso acadêmico, a saber, a reflexão dos coreógrafos sobre seu trabalho no campo da cultura, de acordo com Pierre Bourdieu (Xavier Le Roy, Boris Charmatz, Thomas Lemen). A dança, assim como a prática teatral em geral - muito mais do que na década de 1990 -, está constantemente criticando, refletindo e exibindo seu status problemático como estética ou nada mais do que prática estética, muitas vezes rejeitando a produção aparentemente ingênua de uma ficção estética fechada apresentada à contemplação.

Autores e diretores cada vez mais experimentam as possibilidades da dança e da coreografia, incluindo a dança em seus trabalhos. Falk Richter, por exemplo, colaborou repetidamente com o coreógrafo holandês Anouk van Dijk - como em Trust, no qual os problemas de credibilidade social, financeira e individual, os temas do cansaço de si como discutidos por Alain Ehrenberg, são articulados em uma nova 
forma de dança teatro, criada por um autor literário em colaboraçáo com o coreógrafo e os bailarinos durante os ensaios.

Laurent Chétouane, anteriormente reconhecido por sua concentração aparentemente exclusiva na palavra e no texto, tem trabalhado por alguns anos com a co-presença de atores e bailarinos e, ao mesmo tempo, encenado textos poderosos (Hölderlin, Lenz, Büchner, Brecht, Sêneca, Kleist). Ele convida os espectadores a compartilhar um estado de estar coletivo no palco sem as máscaras da forma altamente estilizada ou da fácil identificação emocional. Nesse tipo de trabalho, náo encontramos, de forma alguma, um retorno ao Tanztheater da década de 1980 (quando a dança detinha a liderança inquestionável), mas uma nova prática na qual a dança torna-se uma parte intrínseca dos projetos maiores de um autor, de um diretor ou de um autor-diretor em colaboração com coreógrafos e bailarinos. A questáo aqui é a exploração pós-dramática de uma coreografia em todas as direçóes - gesto e dança entrando em jogo como um comentário silencioso e questionador sobre o texto falado; a palavra estabelecendo novas formas de diálogo com o espaço e o gesto do corpo presente e dançante. Nesse palco-paisagem, a subjetividade individual tende a tornar-se parte de um horizonte maior. Heiner Müller diz: "em toda paisagem o eu é coletivo" (1983, p. 101).

Podemos relacionar o interesse geral pela dança a um interesse maior pelos aspectos coreográficos da mise-en-scène. Há os espaços coreografados, os movimentos e as pequenas danças no trabalho de Christoph Marthaler, especialmente com Anna Viebrock; há os elementos poderosos dos padróes coreográficos, rítmicos e gestuais das produções de Michael Thalheimer, que frequentemente realiza uma separaçáo interessante: entre gestos fortes e movimentos corporais e uma paralisação rigorosa do corpo, quando os atores falam seus textos, muitas vezes de forma rápida. Podemos falar aqui sobre a ruptura com a representação naturalizante. Enquanto a representação dramática tradicional de Lessing a Stanislavski tenta criar uma impressão de comportamento natural, essa lógica é abandonada aqui em favor do princípio de uma exposição consciente, de algum modo brechtiana, de uma linguagem geralmente altamente artificial e - paralelamente - um repertório de gestos precisos e movimentos corporais. 


\section{Narraçáo e Teatro do Ato da Fala}

Outra tendência - a de número cinco - talvez possa dissipar alguns preconceitos a respeito do papel e importância da palavra. A linguagem do corpo não é tudo. Agora pode ser observada uma nova importância do texto, da palavra, da narrativa acima de tudo, que havia sido substituída no início das décadas de 1980 e 1990 por exploraçóes visuais, mesmo que a dimensão verbal nunca tenha realmente desaparecido. Agora há um grande número de trabalhos teatrais baseados em textos épicos e romances. Os diretores, muitas vezes, preferem textos épicos, narração, ou mesmo comentários ou textos teóricos, ao invés de textos dramáticos. $\mathrm{O}$ teatro tem desenvolvido inúmeras maneiras de contar histórias sem cair na tradição da representação dramática realista e da ficção fechada. Às vezes, a referência à narração fílmica entra em jogo. Diretores como Robert Lepage fazem uso sofisticado do estilo cinematográfico, vídeo, filme, narração épica, colagem e outros dispositivos tecnológicos. $\mathrm{Na}$ Polônia, Grzegorz Jarzyna montou Das Fest a partir do filme de Vinterberg, que pertence ao movimento Dogma; vários teatros na Alemanha também o fizeram. Em 2001, Peter Greenaway apresentou uma produçáo chamada Gold em Frankfurt. É interessante notar que Angela Schalenec, da New Berlin School of Filmmakers, também trabalha com teatro - a assim chamada Berlin School concentra-se no estilo de narração que é conscientemente desdramatizado e que enfatiza a paciente observação das atividades cotidianas. Pode-se argumentar que esse tipo de tendência no cinema e no teatro pósdramático está inter-relacionado de maneira que ainda têm de ser teoricamente exploradas.

A ênfase renovada na narrativa é combinada ao interesse renovado pelo texto em mais uma direçáo. Alguns dos momentos mais impressionantes do teatro contemporâneo destacam metaforicamente (e, às vezes, de verdade) o ator ou performer nu e parecem ser impulsionados pelo desejo de fazer-nos conscientes da maravilha, por assim dizer, do puro ato de falar, do confronto físico e mental dos espectadores com o corpo falante em sua simplicidade mais básica (que, de fato, constitui uma complexidade de ordem mais elevada). Em alguns trabalhos, encontramos um forte impulso em direção ao ator como performer, um impulso que é acompanhado por uma resistência a toda simples teatralidade: cenário, figurino, gestos bem estudados, 
reforço através da música e efeitos de iluminação. Proponho chamálo de teatro de ato-de-fala. Podemos pensar em Dimiter Gotscheff, que, inspirado em Heiner Müller, desteatraliza o teatro e marca a cena com uma apresentação textual concentrada em configurações radicalmente minimalistas - espaços muitas vezes concebidos por Mark Lammert. A fala, o texto e a palavra estabelecem nesse e em outros casos uma relação íntima que supera a quarta parede, permitindo que o teatro se torne um espaço para o pensamento e reflexáo, interrompendo a apreensão puramente estética com uma implicação instigante do espectador, que é forçado a seguir essa redução radical da teatralidade e estabelecer uma relação extraordinariamente intensa com o ato de fala puro do performer. Os trabalhos reduzidos e minimalistas de Laurent Chétouane provocam o público com uma concentração hiperbólica no texto e no ato de falar. Os espectadores não encontram nenhum drama ou identificação com o personagem fictício, mas têm de lidar, ao invés disso, com a presença real do(s) ator(es). Esse tipo de teatro permite que os espectadores experimentem uma profunda relação com o ator/performer - embora muitos saiam do teatro decepcionados porque o espetáculo esperado lhes foi negado. Mas trabalhos desse tipo não indicam, de forma alguma, um retorno do teatro à dramatização convencional ou a um simples retorno do texto - mesmo que eles sejam facilmente mal compreendidos exatamente dessa maneira. Ao invés disso, eles são compreensíveis apenas como uma intrusão de elementos da prática da performance no teatro, o que pode, às vezes, ofuscar, mas também, como nesses casos, enfatizar o material textual. É a realidade física e mental do ato de falar, ou da performance como fala e da performance da fala, que estáo no centro desse teatro. Trata-se do ato físico e real da fala, da situação do performer e do espectador em um confronto íntimo; trata-se da performance - e não de uma preocupação exclusiva ou predominante com o texto, - que pode ou não ser dramático, como já foi demonstrado por uma de suas últimas produçóes de Laurent Chétouane: o conto de Kleist, Terremoto no Chile.

Deter-me-ei aqui com minha visão geral e superficial das (cinco) tendências da última década que considero significativas, e irei agora à primeira de algumas questóes com muito boas razóes para serem discutidas. 
Ao levar em conta os desenvolvimentos desde 1999, será que há alguma necessidade de se revisar, de modo essencial, a noção de teatro pós-dramático? Minha impressão é a de que não há. Sinto que as categorias usadas no livro continuam a valer para a descriçáo de grande parte dos trabalhos novos. Armin Petras, Nicolas Stemann, Falk Richter, Sebastian Hartmann, Stefan Pucher e tantos outros - todos partem da situação frontal do teatro literário, adotam o coro ou o espaço totalmente aberto, práticas que podem implicar elementos dramáticos, mas que fazem amplo uso da substituição da história dramática e da significação legível através da performance, do teatro físico, da interatividade e da abertura do espaço ficcional ao theatron. O trabalho de Heiner Goebbels é tomado por muitos como representativo do estado atual das coisas na linguagem teatral, mostrando-se obviamente bastante pós-dramático, incluindo pintura, filosofia e música, criando uma conexão entre o teatro e a instalação, como, por exemplo, em Stifters Dinge.

$\mathrm{Na}$ Alemanha, o termo pós-dramático teve mais importância, nesse meio tempo, do que o Teatro do Diretor contemporâneo. A palavra aparece em dicionários e na crítica de teatro. A mais importante revista alemã de teatro publicou a palavra em negrito na sua capa três vezes e envolveu-se em uma discussáo crítica sobre ela, alegando, em uma edição de 2009, que a palavra de ordem pós-dramático havia dominado a discussão nos últimos dez anos. Alguns artistas referem-se explicitamente ao termo (na sua página de internet, o Rimini Protokoll chamou seu trabalho de pós-dramático) e alguns diretores o aceitam em suas produçôes. E eu observo com prazer que o Teatro Pós-dramático, também, parece ser útil nas novas tendências da pedagogia teatral.

Em um relatório sobre a cena teatral francesa, publicado pela Theater der Zeit, Bruno Tackels (2005) afirmou já no início que tomaria o Teatro Pós-dramático como uma linha-guia para o seu relatório. Para minha surpresa, críticos, especialistas e profissionais do Japão, América Latina, Austrália, Polônia, Espanha e da região dos Balcâs consideram e continuam considerando o livro útil. Traduçóes continuam a ser publicadas (quinze até agora), e há uma ampla recepção e discussão do termo e do livro, mesmo em áreas onde eu não esperava haver qualquer interesse: Brasil, Argentina, Chile e Colômbia, por 
exemplo. Performing Literatures, no número sobre a pesquisa em performance de março de 2009, oferece bons argumentos de que o termo, assim como é teorizado no livro, manteve um certo "valor de uso". Ele é um ponto de referência em muitos artigos e usado para analisar a performance e a escrita (Tim Crouch, Jelinek, Kane); ele pode ser usado de modo produtivo, questionado e criticado na exploração da relação complexa entre o drama e o teatro. No discurso acadêmico, assim como no crítico, o termo pós-dramático é usado com bastante regularidade, muitas vezes em estreita relaçáo com a performance e/ou o teatro experimental em geral.

Apesar das críticas de um tipo diferente, suponho que é geralmente aceito que a noção tem sido útil e produtiva a) ao apontar para uma expansão dramática das possibilidades, tecnologias e estéticas da prática teatral; b) ao apontar para a importância central de se superar uma associaçáo demasiadamente próxima nas mentes dos espectadores e críticos de teatro com o gênero literário do drama; c) ao ampliar a perspectiva de teatro/performance como uma prática que transcende as divisões entre a arte, a prática social e o teatro, e que é melhor analisada como um limite da arte.

Nos discursos acadêmico e crítico, o termo pós-dramático é usado com bastante regularidade, muitas vezes em estreita ligaçáo com a performance e/ou o teatro experimental em geral. Logo, eu não vejo a necessidade de se falar em teatro pós-pós-dramático ou coisa similar.

\section{II}

O problema teórico da interação e do conflito entre $o$ teatro e o drama que eu enfatizo permanece, como eu o vejo, como uma ferramenta com a qual se pode repensar a tradiçáa europeia do teatro dramático, assim como a tradição europeia de sua teoria. Minha proposta da sequência pré-dramático, dramático e pós-dramático, embora, às vezes, vista como um tipo de processo hegeliano, é uma tentativa de repensar o desenvolvimento do teatro europeu do ponto de vista da prática contemporânea. E a tensão interna e até mesmo, como já foi dito, a contradictio in adjecto entre o drama e o teatro na noção de teatro dramático é uma questáo que precisa e merece maior aprofundamento. Como foi defendido em Teatro Pós-dramático, a definição hegeliana de beleza já é, na sua própria dialética, questio- 
nada, perturbada, rompida, no âmbito do drama, por um elemento irredutível do acaso, da náo-beleza, uma predominância do particular sobre o geral - nem que seja apenas na pessoa do ator que está usando a máscara e se apropriando do belo para sua própria personalidade idiossincrática e particular. O teatro pós-dramático é, nesse sentido, um teatro da era da autorreflexão do conceito do belo, passível de ser considerado um limite da arte, conscientemente questionando seu próprio status de objeto de contemplação e tornando-se um elemento em diferentes tipos de prática (social, política, pedagógica, documental). A proposta de Jean-Pierre Sarrazac (2012) foi de que a noçáo de teatro rapsódico poderia ser mais respeitosa para se compreender o movimento geral da prática do teatro contemporâneo. Essa noção refere-se a Brecht, o ator brechtiano e a Bernard Dort, que parece haver cunhado o termo teatro rapsódico. Por mais útil que o termo seja para uma série de abordagens do teatro nas quais a dimensão textual permanece no centro, a ideia de rapsódico parece estar demasiadamente enraizada nas tradiçóes dramática e brechtiana $\mathrm{e}$, tanto quanto posso ver, não leva devidamente em conta todas as dimensóes do teatro que o trazem para perto de aspectos não literários ou menos literários, como a performance, a instalação, a dança e assim por diante. Sendo assim, não vejo necessidade de substituir o pós-dramático pelo rapsódico.

\section{III}

Como o livro náo foi capaz de tornar suficientemente claro, o termo pós-dramático deve ser compreendido em termos de reflexáo histórica em dois níveis. Por um lado, o termo pós-dramático deveria funcionar como um termo crítico e polêmico que distinguiria uma série de práticas teatrais que eu havia pesquisado (aproximadamente desde a década de 1970 e cercado, como também permeado pelo advento da cultura da performance, predominantemente midiatizada), as quais eram, muitas vezes, ainda guiadas pela ideia do teatro centrado em torno da estrutura dramática, condizente com a tradição dos séculos XVIII e XIX. Já que, em uma paisagem rica e influente (e, muitas vezes, ainda muito criativa) de teatros institucionalizados na Europa, o dramático tende a ser tomado como $o$ modelo natural do que o teatro deveria ser, ainda é necessário, mesmo dez anos mais tarde, salientar que numerosas práticas que se afastam mais ou menos radicalmente desse modelo podem alegar que representam o teatro 
vivo, autêntico e significativo de hoje. O Teatro Pós-dramático não trata simplesmente da morte do drama (ou do texto, ou do autor), mas de uma mudança de ponto de vista das realidades teatrais contemporâneas.

Ao mesmo tempo, o livro claramente indica (por implicação, mais do que argumento) a tese de que o modo dramático de teatro - no sentido preciso que eu posso dar à noçáo por trás desse termo dramático, com base em Hegel, Szondi, Brecht, entre outros - muito provavelmente não será reanimado no futuro. Ao invés disso, há fortes argumentos que podem ser feitos a favor dessa tese, de que a ideia de dramático de fato aponta na direção de algum dado antropológico eterno - o que é provavelmente o caso do teatro -, mas que se refere apenas a um conceito de teatro muito específico, historicamente limitado e particularmente europeu, que está possivelmente - e eu diria provavelmente - prestes a perder terreno. Nesse nível, o termo pósdramático ecoa a noção de pré-dramático que eu usei com a tragédia grega e significa que as condiçóes históricas para o modo dramático de teatro estáo desaparecendo de uma maneira mais fundamental. Nesse sentido, o termo pós-dramático indica não a soma de novas estéticas teatrais desde a década de 1970 até a década de 1990, mas todo o teatro, em suas formas anteriores e posteriores, que não é mais dominado pelo modelo dramático. $\mathrm{O}$ conceito pode até mesmo, assim, ser considerado útil na análise de padróes culturais ou hábitos mais gerais - uma questáo que veio à tona nesse meio tempo.

\section{IV}

Por outro lado, há discordância sobre o uso do termo teatro, uma disputa que coloca em jogo a relação entre o teatro pós-dramático e a performance e, às vezes, no nível institucional, entre os Estudos Teatrais e os Estudos da Performance. Ainda náo estou convencido de que faz muito sentido desistir do termo teatro e subsumir toda a prática teatral ao termo performance. Qualquer que seja a definição que tomamos como critério para definir a performance, é óbvio que o teatro, assim como outras práticas artísticas avançadas, adotou elementos da performance (autorreferencialidade, desconstruçáo de significado, exposição do mecanismo interno do seu próprio funcionamento, mudança da atuação teatral para a performática, questionamento da estrutura básica da subjetividade, repúdio - ou pelo menos crítica e exposição da representação - e iterabilidade), 
enquanto a performance, inversamente, se tornou teatralizada de muitas maneiras, de modo que, com as manifestaçóes artísticas mais importantes, é improdutivo discutir a definição de performance ou de teatro. Há algumas dimensóes do teatro pós-dramático que simplesmente não são performance: dramaturgia visual, híbridos de teatro, instalaçôes e outros. Assim, sem ocupar aqui o debate sobre a performance, no qual Rose Lee Goldberg, Elinor Fuchs, Peggy Phelan, Philip Auslander, Josette Féral, entre outros intervieram, irei apenas indicar, de forma sucinta, que, na minha opinião, não há a necessidade de se estabelecer uma linha divisória clara entre o teatro e a performance. A Teoria da Performance e a Teoria do Teatro operam em bases comuns. Dependendo de seu ponto de vista, você ganha diferentes percepçóes desse terreno comum. Muitos estudos sobre a presença e o futuro da performance são contribuiçóes importantes à compreensão tanto do teatro quanto da performance, mas de maneira alguma necessariamente implicam a subordinaçáo de todo o teatro à noçáo de performance. É muito provável que, por um lado, os pensadores europeus sejam tendenciosamente a favor da noção de teatro, confrontados como os sáo com a rica tradição dramática e o vigor experimental do teatro contemporâneo, mas, por outro lado, é também possível que, em culturas nas quais o teatro é experimentado na maioria das vezes de formas excessivamente datadas e/ou comerciais, pode ocorrer uma certa distorção da percepção, levando à tentação de se descartar com demasiada rapidez o teatro como um todo, favorecendo a performance. Mesmo que o teatro possa ser definido, de modo abstrato, como um subgênero da atividade performática em geral, ele merece e precisa ser estudado em si mesmo, e não apenas à luz da abordagem de amplo espectro, de Richard Schechner (1990). Isso implica, especialmente em nossos tempos de rápida perda de consciência histórica, uma insistência na reflexão e na conscientização histórica. $\mathrm{O}$ termo teatro pós-dramático tem a vantagem de apontar para o fato de que, mesmo atualmente, tanto artistas do teatro quanto da performance são confrontados com as normas e os ideais duradouros da tradição dramática; e, também, em suas próprias consciência e prática eles são, assombrados pelo pano de fundo do drama, náo apenas de modo inconsciente. Somente se em um tempo futuro ou espaço cultural não houvesse qualquer traço ou memória do teatro dramático, então, sem dúvida, a noção de pós-dramático perderia seu significado. 
Há outra questão terminológica que permanece no fundo dessas disputas: a proximidade da noção de performance e do conceito mais abrangente de performatividade em geral. Confesso ser um pouco cético com relação ao conceito de performativo. Essa é a razão pela qual me referi em Teatro Pós-dramático à noção de aformativo, de Werner Hamacher (Lehmann, 2007). O termo performativo náo pode ser completamente dissociado da ideia de um funcionamento bem sucedido, um ato positivo, a realização de um objetivo - há, desde o início, um viés ativista conectado a essa noção: como fazer coisas com as palavras. Essa tendenciosidade obviamente não faz com que a noção seja inútil para descrever muitas características da prática artística, no entanto, ela tende a esconder um aspecto da arte em geral e do teatro/performance em particular que, do meu ponto de vista, é de extrema importância: uma certa passividade, uma náo-realizaçáo no espírito do "eu preferiria não", de Bartleby. Para se dizer o mínimo, muito do teatro performático/pós-dramático constitui a articulaçáo de uma dúvida profunda sobre o fazer, a obtenção, a realização e a performance. A performance tornou-se, como tem sido demonstrado de forma convincente, o novo paradigma da sociedade disciplinar - "performe ou senão..." (McKenzie, 2001, s/p). E um dos aspectos mais produtivos desse conceito é a análise de Judith Butler (1990) da produção performativa da identidade (de gênero). Mesmo que a performance seja uma reflexão da sociedade na qual a ela se tornou uma imposição, não vejo a necessidade de abandonar o paradigma teatro, o que não implica uma associação com o viés ativista (e nos permite levar em conta ainda melhor as práticas críticas da subversáo irônica dos padróes estabelecidos de performatividade como idealizados por Judith Butler).

V

Uma última questão: uma realidade básica do teatro pósdramático é obviamente o desvio da atenção e ênfase na representação - ou Darstellung de um trabalho ou processo - para a criação/ presentificação como parte de uma Situação na qual a relação entre todos os participantes do evento torna-se um objeto importante do conceito artístico e da pesquisa. A noção de dramaturgia do espectador aponta para esse desenvolvimento. $\mathrm{O}$ teatro está seguindo um movimento que nas já foi estabelecido nas artes visuais há décadas. A polêmica notória de Michael Fried (1998) contra a teatralidade 
na arte moderna visava exatamente essa questáo: a dependência do trabalho em relação ao espectador. Essa observação, desprovida de sua intenção polêmica, é útil na descrição da prática pós-dramática, o que frequentemente tende a se concentrar na relação do evento com os espectadores (e a relaçáo entre os espectadores) como o material básico para a elaboração artística. Nicolas Bourriaud (2002) escreve que, nessa arte, que ele descreveu como relacional, as relaçóes sociais podem constituir o material vivo para algumas das práticas em jogo (Precarious Constructions. Answer to Jacques Rancière on Art and Politics). É interessante notar que Bourriaud descreve uma mudança geral na ideia de arte chamada de "estética relacional" que é bastante similar ao teatro pós-dramático: muitos artistas contemporâneos pensam sobre suas práticas não tanto como algo que dá forma a um objeto, mas como a construçáo de uma forma possível de relaçôes humanas. Mesmo que eu estivesse criticando o fato de que Bourriaud enfatiza de um modo muito unilateral, os aspectos harmoniosos, a convivialité dessas práticas artísticas que visam propor outras possibilidades para nossa convivência neste mundo, suas ideias são importantes e úteis para uma elaboração teórica e prática posterior do teatro pós-dramático como um teatro de situação. Depois de levar em consideraçáo os elementos de conflito, distanciamento e polêmica nesses espaços construídos de relação, que, em Bourriaud, são de certo modo sub-representados, a estética relacional contribui para uma melhor compreensão de fenômenos comparáveis, característicos do teatro pós-dramático.

A estética relacional, até onde eu sei, não necessariamente retira da arte sua dimensão estética artística, como argumentou Jacques Rancière. De um modo semelhante, o teatro pós-dramático não perde sua dimensão estética como arte quando abandona sua noção de autonomia e negocia alinhamentos híbridos com as práticas sociais, políticas e outras. Esses debates confirmam a ideia de teatro pós-dramático como um laboratório para se imaginar, inventar e investigar outros tipos de relaçôes humanas através da exploração de novos tipos de espectador e pela invençáo de tipos diferentes de posição para os espectadores. Isso pode com certeza constituir seu caráter verdadeiramente político, mesmo que a intenção do trabalho individual não seja conscientemente política. 


\section{Nota}

${ }^{1}$ NR.: veja a edição em língua portuguesa do livro em Lehmann (2007).

\section{Referências}

AUGÉ, Marc. Non-Lieux. Introduction à une Anthropologie de la Surmodernité. Paris: Seuil, 1992. BOURRIAUD, Nicolas. Relational Aesthetics. Dijon: Les presses du réel, 2002.

BUTLER, Judith. Gender Trouble. New York: Routledge, 1990.

CERTEAU, Michel. L'Invention du Quotidien. Paris: Arts de Faire, 1980.

FRIED, Michael [1967]. Art and Objecthood. Essays and Reviews. London: Chicago University Press, 1998.

KERKHOVEN, Marianne. European Dramaturgy in the 21st Century. Performance Research: a Journal of the Performing Arts, London, v. 14, n. 3, 2009.

LEHMANN, Hans-Thies. Teatro Pós-dramático. São Paulo: Cosac Naify, 2007.

MARANCA, Bonnie; DASGUPTA, Gautam. Interview. In: ENGELHARDT, Barbara; IRMER, Thomas. So wie es bleibt, ist es nicht Gautam Dasgupta und Bonnie Marranca werfen einen amerikanischen Blick aufs deutsche Theater von Barbara Engelhardt, Thomas Irmer, Bonnie Marranca, Gautam Dasgupta. Theater der Zeit, Berlin, n. 2, p. 38-41, 2000.

MCKENZIE, Jon. Perform or Else. From discipline to Performance. London: Routledge, 2001.

MÜLLER, Heiner. Herzstück. Berlin: Rotbuchverlag, 1983.

PAVIS, Patrice. Languages of the Stage: essays in the semiology of theatre. New York: Performing Arts Journal Press, 1982.

PERFORMING LITERATURES. Special Issue of Performance Research: a Journal of the Performing Arts, London, v. 14, n. 1, 2009.

SARRAZAC, Jean-Pierre. Poétique du Drame Moderne. Paris: Seuil, 2012.

SCHECHNER, Richard. Perfomance Studies: the broad sprectum approach. National Forum 70, [s.l.], n. 3, p. 15-16, 1990.

TACKELS, Bruno. An der Bruchstelle zwischen Text und Performance, Momentaufnahmen im französischen Theater. Theater der Zeit, Berlin, n. 9, p. 3-8, 2005.

Hans-Thies Lehmann lecionou nas Universidades de Amsterdam (Holanda), Virginia (EUA), Sorbonne (França), Escola de Belas Artes de Berlim (Alemanha), entre outras. Desde 1988, é professor titular de Ciências Teatrais na Universidade de Frankfurt, onde liderou a implementação dos cursos de Teatro, Cinema e Ciências da Comunicação e de Dramaturgia. Foi responsável pela introduçáo do termo teatro pós-dramático. E-mail: h.t.lehmann@tfm.uni-frankfurt.de

Traduzido do original em inglês por Martin Heuser. Revisado por Marcelo de Andrade Pereira.

Recebido em 06 de maio de 2013 Aprovado em 07 de junho de 2013 